\title{
A Study of Teaching Functional English Writing Skill to Hearing-Impaired Students
}

\author{
XIA Wu-yang \\ Leshan Special Education School, Leshan, Sichuan, China (614000)
}

\begin{abstract}
The writing activities of English teaching for hearing-impaired students in Chinese special education schools are mainly based on the chosen topics given by the teacher teaching the course in light of the regular English Curriculum. These selected topics are often not only rigid but also unrelated to the lives of the students at large. As a result, the writing activities often make students lose interest in English writing in general and yield poor writing results. As such, this paper has come up with some useful and effective evidence-based activities for teaching functional English writing skills closely linked to the lives of the hearing-impaired students at the special education school learning English as a foreign language (EFL). The same teaching strategy can also be applied to the English writing practice for the hearing-impaired students receiving inclusive education at the general school. These useful and effective activities have not only aroused the students' strong interest in English learning but also improved their functional English writing skills which they can apply to their written English communication both in and out of the English classroom.
\end{abstract}

Keywords: hearing-impaired students, English, functional writing, teaching

\section{Introduction}

Harmer (2000, pp. 79-80) holds that teaching English writing to students aims to consolidate the English knowledge, promote the language development, and improve the writing skill of the students as a whole. ZOU (2008, p. 18) also points out that activities for teaching English writing have two purposes, one of which is to improve learners' English writing skill and the other is to help them continue to consolidate and improve their English language skill. These two purposes are closely related to each other. For example, students cannot write in English without acquiring the basics of the language. However, if students write just for the sake of writing instead of communicating ideas as its goal, such a writing would be hollow, boring, and useless, often leading to poor interest and low academic achievement in their English learning.

DENG (2011, p. 193) noted that SI surveyed a group of 48 Chinese secondary school students on their English writing learning and found 92\% of them are afraid of writing English composition, 58\% do not know how to write, $72 \%$ have limited vocabularies, and 33\% have problem composing an essay. In addition, many topics for writing English compositions are boring and unrelated to the life experience of the students, such as "My Visit to an Old Town”. Students find it hard to write this composition because quite a few of them have never been to an old town. So they have no choice but to imagine a trip to an old town when they write it. Such a kind of writing based on mere imagination is all but boring, less readable, and lack of authenticity. Other English writing

XIA Wu-yang, MA in Special Education, Leshan Special Education School, Leshan, Sichuan, China (614000). 
teaching challenges include lack of practical writing practice, writing for the sake of writing like tests, and too much emphasis on grammatical accuracy over communicative competence (WANG, 2006, p. 212).

In spite of the fact that many studies have been carried out on how to improve the English writing skill of the students without SEND (Special Educational Needs and Disabilities), so far very few such studies have been made to help improve the English writing skill of the students with SEND, especially the functional English writing skill of students with hearing impairment. So this paper will study evidence-based methods the author has used to teach functional English writing activities, and develop the functional writing skill of the hearing-impaired students based on their particular cognitive competence, their ways of learning English and learning interest due to their disability.

\section{Goals and Principles of Teaching Functional English Writing to Hearing-Impaired Students}

In view of the above-mentioned problems in traditional English writing teaching and training for students with hearing impairment, the author teaches the functional English writing skill to his hearing-impaired students according to his students' actual English learning situation. The goals aim to help students apply what they learn to practice in order to fulfill the communicative function of language and the principles are designed to link the students' learning to their life so that they can acquire the English writing skill through learning by doing. CHEN (2010, pp. 55-56) also echoes that only through daily communicative language activities can students faster and better gain the English writing skill and live up to such learning goal and principle.

\section{Teaching Goals}

Hearing impaired students can review and consolidate their English knowledge and skills through English writing, especially functional English writing activities. By doing so, students can not only long retain the knowledge they have obtained, but also deepen and broaden their understanding of the knowledge, thus improving their English writing ability. Another goal of teaching functional English writing skill is that it can provide students with a vivid and real language environment in which they can improve their functional English writing skill (WANG, 2016, p. 56). In addition, students can communicate ideas through functional English writing activities to maintain interpersonal relations and achieve the function of social communication at large (Halliday, 1979).

\section{Teaching Principles}

Marschark and Hauser (2012, p. 101) comment that English teachers must regard English writing as a language communicative ability to cultivate and create a kind of communication environment close to life for students to improve their functional English writing ability. This principle is also echoed by LI (2015, p. 104) that English teachers should adhere to this kind of communicative principle in teaching organization, methods as well as process so as to promote the functional English writing skill of students in general. Furthermore, teachers should connect the content of English writing with the life and interest of the hearing-impaired students, because English writing is not equal to writing composition but should become a way of daily communicative activity. Teachers can instruct students to write things such as shopping lists, notes, or emails in English. These practical writings can be long or short depending on the circumstance but they must have a clear objective of communication and are also closely connected to students' daily life, so that students can have something to say when writing them. 


\section{Functional English Writing Activities for Hearing-Impaired Students}

Functional English writing activities aim to link English writing opportunities in learning and life with English composition training in class, complement each other, and promote the synchronous development of both. Functional English writing can effectively help students with hearing impairment to master basics of English writing and improve their fluency and communicative competence in English writing through learning by doing (Foreman et al, 2004). What's more, the content and form of the writing activities should be closely associated with students' life experience and flexible and interesting depending on the learning situation. Ministry of Education (2016, pp. 26-27) requires that learning activities should be executed not only in class but also out of class, extending learning beyond the classroom. In addition, Functional writing should often be taught concurrently with functional reading, a task to be fulfilled through reading (JIANG, 2007, p. 58), which can improve hearing-impaired students' reading skills by providing practice with a variety of formats and situations they are likely to come across in life (Polloway \& Patton, 1997).

\section{Dictation}

Dictation is a basic communicative writing activity suitable for middle school students with hearing impairment. The English teacher may proceed step by step with this activity according to the student's actual English level. The dictation material may be the new words, phrases and sentence and the short passages from the English textbook the students study. When implementing dictation, the teacher can use both English and sign language to meet the learning needs of students with some hearing ability and students without it. After dictation, the teacher can use PPT to display the dictation content for students to check their writing and, at the same time, explain those words that are easily misspelled, such as some homonyms: "there and their", "Its and It's". The teacher should also teach the students how to use the dictation contexts to correctly write down the things they hear and understand their meanings. ZOU (2008, p. 18) states that repetitive dictation of some difficult words, if necessary, should be executed until students master them, for repetition can noticeably improve the students' writing speed, accuracy and competence due to meaningful and constant practice and reinforcement (Bos, 1982).

\section{Imitative Writing}

Imitative writing is an indispensable training activity for English beginners to learn English writing skills, and can also lay a solid foundation for functional English writing that follows. For instance, under the careful instruction and guidance of the teacher, the hearing-impaired students can first imitate the sentences and texts on family learned from the text and then go on to write their own family, such as "My name is Li Ying and I'm a student at a special education school. This is my mother. She is a school teacher. That is my father. He works in a company”. With more practice, students can read and write English name cards, forms, and notes and so forth. Imitative writing must be combined with reading, proceeding from reading to writing and from easy to difficult materials. However, as dictation and imitative writing are both controlled and mechanical writing practices which are effective for improving writing fluency and accuracy, they should not be overused because there are some limitations in cultivating students' autonomous learning and critical writing ability (Peace Corps Information Collection and Exchange, 1989, pp. 135-136; ZOU, 2008, p. 102).

\section{Writing English Cards}

After mastering basic English knowledge and skills, teachers can arrange for students with hearing 
disabilities to participate in some simple and practical functional writing activities such as designing and writing different kinds of English cards, personal cards, shopping lists, menus and simple charts. This kind of functional English writing training is relatively simple and practical, most of which don't need writing many words and sentences, but all have clear communicative objects and purposes. For instance, when instructing students to write personal name cards, the teacher can introduce the different cultural expressions and correct ways to write English and Chinese people names and place names by using the related content of the textbook, so as to cultivate and raise students' awareness and ability in cross-cultural communication (Chen \& Greenall, 2015, p. 7).

\section{Writing Forms}

The activities for students with hearing impairment to fill in various English forms must be combined with related functional English reading activities. The teaching content selected by the teacher must be suitable for the students' English level and ability. If the content is too difficult, the students cannot complete the task. If the content is too easy, the student cannot learn much from it. With more practice, the teacher can gradually increase the degree of difficulty in such functional reading and writing activities, and help students to fill out English forms with certain difficulty, such as registration forms and application forms and so on. These functional reading and writing training activities can synchronously help to develop students' ability to read and write in English.

\section{Writing Notes}

English note writing is another good way to teach functional English writing to students with hearing impairment. With the improvement of students' English level and skills, teachers can use some functional English writing activities which are more difficult like note writing according to students' English levels. These note writing activities may include leave notes, IOUs, and simple invitation cards. This functional English writing activity is closer to students' life and can lay a solid foundation for future practical English writing. For example, students can imitate the following leave note and come up with their own leave notes.

Dear Ms Liu,

I am writing to ask for a leave this afternoon because I need to see a doctor for my cold. I will be back before five this afternoon.

Thank you!

Your student, Li Hong

\section{Writing With Social Media}

Teachers should also keep up with the times and help students to use social media like E-mail, QQ, or Wechat widely available in China to improve the functional English writing ability of students with hearing impairment. These social media tools all have something in common: an open and interactive writing communication platform and very convenient and fast. There are many advantages of employing them for the benefit of teaching functional English writing skills. For example, students with hearing-impairment can directly use E-mail, QQ, or Wechat to finish their writing assignments and hand them in to the teachers who can then send the revised copies back to students in time, which improves the efficiency and effectiveness of teacher-student interaction. In addition, students can share their writings with one another on these social media platforms where they can discuss questions related to their writing and thus learn from each other in an interactive manner. When writing in the context of social media, students often feel like writing in a real 
communicative language environment without the restraint of formal writing based on assigned topics in the traditional classroom. At this stage of relatively advanced functional English writing practice, teachers should center on cultivating and improving students' independent and critical writing communication skills.

\section{Conclusion}

On the basis of what was said above, English teachers can creatively and flexibly carry out the functional English writing activities according to the actual English competence of students with hearing impairment and combine in-class and out-of-class training activities to improve their functional English writing skill at large. The teachers should also flexibly adjust the content, form and difficulty of these functional writing activities to meet the diverse learning needs of their students resulted from their own cognitive competence and learning habits. WANG (2006, p. 227) emphasized that in the implementation of these functional writing activities, the focus should be on the process rather than on the result and all the activities must have a clear and real communicative purpose. In addition, the functional English writing activities should be student-centered instead of teacher-centered and combined with functional reading activities but the teachers' timely instruction, guidance and feedback for such communicative-based writing activities are also necessary and important.

\section{References}

Bos, C. S. (1982). Getting past decoding: Assisted and repeated readings as remedial methods for learning disabled students. Topics in Learning and Learning Disabilities, 1(4): 51-57.

CHEN, Y. (2010). Construction of a language communication-based English class in the deaf school. Modern Special Education, 7-8, 55-56.

CHEN, L., \& Greenall, S. (2015). English for Grade 7, Book 1. Beijing: Foreign Language Teaching and Research Press.

DENG, D. X. (2011). New English curriculum in high school: Ideas and practice. Chengdu: Sichuan Education Press.

Foreman, P., Arthur-Kelly, M., Pascoe, S. \& King, B. S. (2004). Evaluating the educational experiences of students with profound and multiple disabilities in inclusive and segregated classroom settings: An Australian perspective. Research and Practice for Persons with Severe Disabilities, 29, 183-193. doi:10.2511/rpsd, 29 (3):183.

Halliday, M. A. K. (1979). Towards a sociological semantics (extracts). In C. J. Brumfit \& K. Johnson (Eds.), The communicative approach to language teaching. Oxford: Oxford University Press.

Harmer, J. (2000). How to teach English. Beijing: Foreign Language Teaching and Research Press.

JIANG, D. (2007) Teaching reading to hearing-impaired children: Challenge but also an important task in the practice of audiology. Chinese Scientific Journal of Hearing and Speech Rehabilitation, 1, 58.

LI, X. (2015). A study of English teaching at schools for the deaf based on the communicative approach. Journal of Changchun Education Institute, 9, 104.

Marschark, M., \& Hauser, P. C. (2012). How deaf children learn. Oxford: Oxford University Press, Inc.

Ministry of Education of P.R.C. (2016).Compulsory education English curriculum standards. Beijing: Beijing Normal University Press.

Peace Corps Information Collection and Exchange. (1989). TEFL/TESL: Teaching English as a second or foreign language. Washington: Center for Field Assistance and Applied Research.

Polloway, E. A., \& Patton, J. R. (1997). Strategies for teaching learners with special needs. New Upper Saddle River, Jersey: Prentice-Hall, Inc.

WANG, Q. (2006). A course in English language teaching. Beijing: Higher Education Press.

WANG, Y. (2016). A practical exploration of English teaching in deaf schools based on constructivism. Modern Special Education, 7, 56.

ZOU, W. C. (2008). Developing professional skills of teaching foreign languages. Beijing: Higher Education Press. 